\title{
PENGARUH KOMPENSASI FINANSIAL DAN KEPUASAN KERJA TERHADAP KOMITMEN ORGANISASI PADA PT. ASURANSI SINARMAS CABANG DENPASAR
}

\author{
Herland Nurtika ${ }^{1}$ \\ Ni Ketut Sariyathi ${ }^{2}$ \\ ${ }^{1,2}$ Fakultas Ekonomi dan Bisnis Universitas Udayana (Unud), Bali, Indonesia \\ e-mail: herland250794@gmail.com
}

\begin{abstract}
ABSTRAK
Tujuan dari penelitian ini adalah untuk menganalisis pengaruh kompensasi finansial dan kepuasan kerja terhadap komitmen organisasi. Populasi dalam penelitian ini sebanyak 49 karyawan. Metode penentuan sampel yang digunakan adalah metode sampel jenuh, maka seluruh populasi akan dijadikan sampel. Obyek dalam penelitian ini adalah kompensasi finansial dan kepuasan kerja serta pengaruhnya terhadap komitmen organisasi di PT. Asuransi Sinarmas Cabang Denpasar. Metode pengumpulan data yang digunakan yakni kuisioner dan wawancara. Teknik analisis data yang digunakan adalah regresi linier berganda. Hasil dari penelitian ini adalah kompensasi finansial berpengaruh positif dan signifikan terhadap komitmen organisasi, dan kepuasan kerja berpengaruh positif dan signifikan terhadap komitmen organisasi. Untuk meningkatkan komitmen karyawan, manajer perusahaan perlu untuk memperhatikan jumlah kompensasi finansial yang diberikan khususnya tunjangan dan juga beban pekerjaan yang diberikan kepada karyawan, agar karyawan merasa puas dengan pekerjaannya.
\end{abstract}

Kata Kunci : kompensasi finansial, kepuasan kerja, komitmen organisasi.

\begin{abstract}
The purpose of this study was to analyze the effect of financial compensation and job satisfaction on organizational commitment. The population in this study were 49 employees. Sample determination method used is saturated sample method, then the entire population will be sampled. Object in this research is financial compensation and job satisfaction and its influence to organizational commitment in PT. Asuransi Sinarmas Denpasar Branch. Data collection methods used were questionnaires and interviews. Data analysis technique used is multiple linear regression. The result of this research is financial compensation have positive and significant effect to organizational commitment, and job satisfaction have positive and significant influence to organizational commitment. To increase employee commitment, corporate managers need to pay attention to the amount of financial compensation provided, especially benefits and also the workload given to employees, so that employees are satisfied with their work.
\end{abstract}

Keyword : financial compensation, job satisfaction, organizational commitment 


\section{PENDAHULUAN}

Keberhasilan aupun kegagalan suatu organisasi atau unit kerja dalam melaksanakan tugas dan fungsinya sangat berhubungan erat dengan pelaku-pelaku organisasi tersebut, atau dengan kata lain sumber daya manusia mempunyai peran strategis sebagai penentu berhasil tidaknya pencapaian kinerja dalam suatu organisasi. Karyawan merupakan kekayaan utama bagi perusahaan, dimana mereka akan menjadi perencana, pelaksana dan pengendali yang selalu memberikan peran aktif dalam mewujudkan tujuan perusahaan. Karyawan mempunyai pikiran, perasaaan dan keinginan yang dapat mempengaruhi sikapsikapnya terhadap pekerjaan yang dilakukannya. Sikap ini akan menentukan seberapa besar kecintaanya terhadap pekerjaan yang dibebankan kepadanya, dan loyalitasnya kepada perusahaan. Oleh karena itulah kepuasan kerja karyawan harus selalu dijaga dan dipenuhi sebaik-baiknya oleh pihak perusahaan.

Salah satu masalah yang terkait dengan karyawan yakni masalah komitmen organisasi, kompensasi finansial dan kepuasan kerja. (Spector dkk., 2000) menyatakan bahwa komitmen organisasi menggambarkan sejauh mana individu mengidentifikasikan dirinya dan dilibatkan dengan organisasinya dan tidak ingin meninggalkan organisasinya. Komitmen organisasi dapat didefinisikan sebagai afiliasi karyawan untuk organisasi dan keterlibatan di dalamnya, secara umum ada tiga dimensi komitmen yaitu komitmen berkelanjutan, komitmen afektif dan komitmen normatif (Nawab dan Bhatti, 2011).

Salah satu perusahaan asuransi terbesar di Indonesia yakni PT. Asuransi Sinarmas yang merupakan anak perusahaan dari PT. Sinar Mas Multiartha Tbk. 
PT. Asuransi Sinarmas adalah perusahaan jasa yang bergerak dibidang asuransi, mulai dari asuransi kendaraan, rumah, hingga kesehatan. PT. Asuransi Sinarmas tentu saja memerlukan karyawan dengan kinerja yang sangat baik dan loyalitas yang tinggi terhadap perusahaan. Karena hal itu akan sangat berpengaruh terhadap profit dari PT. Asuransi Sinarmas. Ketatnya persaingan perusahaan asuransi di Indonesia, mengharuskan PT. Asuransi Sinarmas untuk terus meningkatkan pelayanannya kepada nasabah.

Jumlah karyawan yang dimiliki Asuransi Sinarmas yakni 89 orang yang terdiri dari 49 orang karyawan tetap dan 40 karyawan kontrak. Setiap karyawannya memiliki peranan yang sangat penting dalam produktivitas perusahaan. Pendayagunaan sumber daya manusia secara produktif pada Asuransi Sinarmas, tentu saja akan memberikan dampak yang positif bagi perusahaan. Komitmen organisasi karyawan diduga menjadi masalah yang saat ini ada diperusahaan, hal ini didasarkan pada wawancara awal yang dilakukan pada atasan dan karyawan, yang menyatakan bahwa karyawan ingin mencari pekerjaan ditempat lainnya karena kurangnya gaji dan rasa puas mereka dalam bekerja.

Salah satu cara untuk menilai tingkat komitmen karyawan adalah dengan cara melihat tingkat turnover karyawan didalam perusahaan tersebut. Data turnover karyawan PT. Asuransi Sinarmas Cabang Denpasar dapat dilihat pada Tabel 1. Tabel 1 menunjukkan terjadinya penurunan karyawan yang keluar dari tahun 2013 - 2015 sebesar 4,25 persen menjadi 2,02 persen dan mengalami peningkatan pada tahun 2015 menjadi 2,04 persen. Namun pada tahun 2016 tingkat turnover karyawan kembali meningkat menjadi 11,50 persen. Menurut 
(Gillis, 1994) turnover karyawan dikatakan normal berkisar antara 5 persen - 10 persen dan dikatakan tinggi apabila berada diatas 10 persen.

\section{Tabel 1. Data Turnover Karyawan PT. Asuransi Sinarmas}

\begin{tabular}{cccccc}
\hline Tahun & $\begin{array}{c}\text { Jumlah } \\
\text { karyawan } \\
\text { awal tahun } \\
\text { (orang) }\end{array}$ & $\begin{array}{c}\text { Jumlah } \\
\text { karyawan } \\
\text { akhir tahun } \\
\text { (orang) }\end{array}$ & $\begin{array}{c}\text { Rata-rata } \\
\text { karyawan }\end{array}$ & $\begin{array}{c}\text { Karyawan } \\
\text { keluar } \\
\text { (orang) }\end{array}$ & $\begin{array}{c}\text { Karyawan keluar } \\
(\%)\end{array}$ \\
\hline 2013 & 51 & $(2)$ & $(3)=(1)+(2): 2$ & $(4)$ & $(5)=(4):(3) \times 100 \%$ \\
2014 & 50 & 49 & 49,5 & 2 & 4,00 \\
2015 & 52 & 51 & 49 & 1 & 2,02 \\
2016 & 55 & 49 & 52 & 6 & 2,04 \\
\hline
\end{tabular}

Sumber : PT. Asuransi Sinarmas Cabang Denpasar, 2016

Berdasarkan Tabel 1 tingkat turnover karyawan masih tergolong tinggi yang terdapat pada tahun 2016 yang mencapai 11,50 persen. Berdasarkan wawancara dari karyawan, yang menyebabkan tingginya tingkat turnover di PT. Asuransi Sinarmas Cabang Denpasar, selain gaji yang dirasa tidak adil, terdapat juga rasa kurang puas dalam bekerja karena beban kerja yang juga dirasa kurang adil. Hal inilah yang diduga menyebabkan komitmen mereka dalam bekerja menjadi berkurang.

Selain komitmen , masalah kompensasi finansial dan kepuasan kerja oleh atasan diduga juga menjadi masalah yang ada diperusahaan. Kompensasi finansial menurut (Simamora, 2006) terkait dengan gaji yang diterima oleh karyawan tersebut. Menurut (Ardana dkk., 2011: 153) Kompensasi adalah segala sesuatu yang diterima oleh karyawan sebagai balas jasa atas kontribusinya kepada perusahaan atau organisasi. Menurut (Simamora, 2006) pada umumnya komponen kompensasi dapat dibagi menjadi kompensasi langsung (direct compensation) dan 
kompensasi tidak langsung (indirect compensation). Kompensasi finansial langsung (direct financial compensation) terdiri dari bayaran (pay) yang diperoleh seseorang dalam bentuk gaji, upah, bonus. Kompensasi finansial tidak langsung (indirect financial compensation) yang disebut dengan tunjangan meliputi semua imbalan finansial yang tidak tercakup dalam kompensasi langsung. Kompensasi non finansial (nonfinancial compensation) terdiri atas kepuasan kerja yang diperoleh seseorang dari pekerjaan itu sendiri atau dari lingkungan psikologis di mana orang itu bekerja. Tipe kompensasi non finansial meliputi kepuasan yang didapat dari pelaksanaan tugas yang signifikan yang berhubungan dengan pekerjaan.

Penelitian Dewi et al. (2013) menyatakan bahwa kompensasi finansial berpengaruh positif dan signifikan terhadap komitmen organisasi dan juga pendapat dari Hidayat (2015) yang juga menyatakan bahwa kompensasi finansial berpengaruh positif dan signifikan terhadap komitmen organisasi. Penelitian oleh Buraidah et al. (2011) juga menyatakan bahwa kompensasi finansial berpengaruh positif dan signifikan terhadap komitmen organisasi. Ricky et al. (2016) juga menyatakan bahwa kompensasi finansial berpengaruh positif dan signifikan terhadap komitmen organisasi. Arta (2017) Juga menyatakan bahwa kompensasi finansial berpengaruh positif dan signifikan terhadap komitmen organisasi.

Selama ini, menurut karyawan Asuransi Sinarmas, mereka mengeluhkan gaji yang tidak sesuai dengan tanggung jawab dan juga beban kerja yang diberikan. Hal ini diketahui setelah dilakukan wawancara awal untuk semua bagian pada PT. Asuransi Sinarmas Cabang Denpasar. Tabel 2 menunjukkan 
daftar gaji karyawan dari PT. Asuransi Sinarmas Cabang Denpasar. Karyawan administrasi merasa gaji yang diberikan oleh perusahaan untuk bagian administrasi masih dibawah dari tugas dan tanggung jawab yang diberikan.

Tabel 2. Data Gaji karyawan PT. Asuransi Sinarmas Cabang Denpasar Tahun 2016

\begin{tabular}{lcccc}
\hline No. & Jabatan & $\begin{array}{c}\text { Jumlah } \\
\text { Gaji Karyawan Tetap } \\
\text { (Rupiah) / Bulan }\end{array}$ & $\begin{array}{c}\text { Jumlah } \\
\text { Kontrak } \\
\text { (orang) }\end{array}$ & $\begin{array}{c}\text { Karyawan } \\
\text { Tetap } \\
\text { (orang) }\end{array}$ \\
\hline 1 & Pimpinan Cabang & $11.000 .000,-$ & 0 & 1 \\
2 & Marketing Agency & $8.000 .000,-$ & 0 & 1 \\
3 & Ketua BAS & $6.000 .000,-$ & 0 & 1 \\
4 & Wakil Ketua BAS & $5.000 .000,-$ & 0 & 1 \\
5 & Marketing & $2.500 .000,-$ & 2 & 5 \\
6 & Admin Progress & $2.800 .000,-$ & 5 & 5 \\
7 & Admin Quotation & $2.800 .000,-$ & 5 & 5 \\
8 & Admin Kesehatan & $2.800 .000,-$ & 4 & 5 \\
9 & Admin Polis & $2.800 .000,-$ & 5 & 7 \\
10 & Admin Financial & $2.800 .000,-$ & 5 & 3 \\
11 & Admin Klaim & $2.800 .000,-$ & 5 & 9 \\
12 & Admin Marketing & $2.800 .000,-$ & 1 & 2 \\
13 & Driver & $2.000 .000,-$ & 2 & 1 \\
14 & Office Boy & $2.000 .000,-$ & 2 & 1 \\
15 & Telemarketing & $2.000 .000,-$ & 2 & 1 \\
16 & Mesengger & $2.000 .000,-$ & 2 & 1 \\
Total & & & 40 & 49 \\
\hline Simer & PT. Asuran Sing & & \\
\hline
\end{tabular}

Sumber: PT. Asuransi Sinarmas Cabang Denpasar, 2016

Hal ini didapat berdasarkan wawancara awal dari karyawan, karyawan merasa kurang dihargai dalam pemberian gaji karena tidak sesuai dengan pekerjaan yang diberikan oleh perusahaan. Sebagai contoh administrasi kesehatan dan administrasi polis hanya bekerja di dalam ruangan dan tanggung jawabnya relatif lebih ringan, sedangkan administrasi claim, administrasi progress, dan administrasi quotation memiliki tanggung jawab yang jauh dengan nilai gaji yang diberikan dan sangatlah beresiko berada dibagian ini, dan dibagian ini lebih sering bekerja dilapangan daripada bekerja didalam ruangan. Menurut atasan dan 
karyawan sudah banyak dibagian administrasi yang bekerja dilapangan mengundurkan diri dari perusahaan karena tekanan pekerjaan dan gaji yang masih dirasa tidak adil karena beban kerja tersebut.

Selain kompensasi finansial, kepuasan kerja juga diduga berpengaruh pada tingkat turnover yang tinggi tersebut. Kepuasan kerja menurut Robbins (2006) terkait dengan seberapa puas seorang karyawan dalam menyelesaikan pekerjaannya. (Koesmono, 2005) menyatakan bahwa kepuasan kerja merupakan suatu penilaian, perasaan atau sikap karyawan terhadap pekerjaannya dan berhubungan dengan lingkungan kerja, jenis pekerjaan, kompetensi, hubungan antar rekan kerja, hubungan sosial di tempat kerja dan sebagainya. Menurut (Sutrisno, 2012) kepuasan kerja karyawan merupakan masalah penting yang diperhatikan dalam hubungannya dengan produktivitas kerja karyawan dan ketidakpuasan sering dikaitkan dengan tingkat tuntutan dan keluhan pekerjaan yang tinggi. Secara umum kepuasan kerja adalah salah satu aspek psikologis yang mencerminkan perasaan seseorang terhadap pekerjaannya.

Penelitian Chandra (2014) menyatakan bahwa kepuasan kerja berpengaruh positif dan signifikan terhadap komitmen organisasi, dan juga pendapat yang sama dari Dewi et al. (2013) menyatakan bahwa kepuasan kerja berpengaruh positif dan signifikan terhadap komitmen organisasi. Penelitian dari Puspitawati et al. (2014) juga meyatakan bahwa kepuasan kerja berpengaruh positif dan signifikan terhadap komitmen organisasi. Sijabat (2011) Juga menyatakan bahwa kepuasan kerja berpengaruh positif dan signifikan terhadap komitmen organisasi. Kartika (2012) juga menyatakan bahwa kepuasan kerja berpengaruh positif dan signifikan 
terhadap komitmen organisasi. Tingkat kepuasan kerja karyawan dapat dinilai dari tingkat absensi pada Tabel 3.

Tabel 3. Tingkat Absensi Karyawan PT. Asuransi Sinarmas Cabang Denpasar Tahun 2016

\begin{tabular}{|c|c|c|c|c|c|c|c|}
\hline \multirow[t]{2}{*}{ No. } & \multirow[t]{2}{*}{ Bulan } & \multirow[t]{2}{*}{$\begin{array}{c}\text { Jumlah } \\
\text { karyawan } \\
\text { (orang) }\end{array}$} & \multirow[t]{2}{*}{$\begin{array}{c}\text { Jumlah } \\
\text { Hari Kerja } \\
\text { Per Bulan } \\
\text { (hari) }\end{array}$} & $\begin{array}{c}\text { Jumlah Hari } \\
\text { Kerja } \\
\text { Seharusnya } \\
\text { (hari) }\end{array}$ & $\begin{array}{c}\text { Jumlah } \\
\text { Absensi } \\
\text { Per Bulan } \\
\text { (hari) }\end{array}$ & $\begin{array}{c}\text { Jumlah Hari } \\
\text { Kerja } \\
\text { Sesungguhnya } \\
\text { (hari) }\end{array}$ & $\begin{array}{c}\text { Persentase Absens } \\
(\%)\end{array}$ \\
\hline & & & & $(1.2)=(3)$ & (4) & $(3-4)=(5)$ & $(4: 3) \times 100 \%=(6)$ \\
\hline 1 & Januari & 55 & 23 & 1265 & 64 & 1201 & 5,05 \\
\hline 2 & Februari & 55 & 21 & 1155 & 63 & 1092 & 5,45 \\
\hline 3 & Maret & 53 & 23 & 1219 & 63 & 1156 & 5,17 \\
\hline 4 & April & 53 & 22 & 1166 & 60 & 1106 & 5,14 \\
\hline 5 & Mei & 53 & 23 & 1219 & 59 & 1160 & 4,84 \\
\hline 6 & Juni & 50 & 22 & 1100 & 59 & 1041 & 5,36 \\
\hline 7 & Juli & 50 & 23 & 1150 & 60 & 1090 & 5,21 \\
\hline 8 & Agustus & 50 & 23 & 1150 & 57 & 1093 & 4,95 \\
\hline 9 & September & 50 & 22 & 1100 & 58 & 1042 & 5,27 \\
\hline 10 & Oktober & 49 & 23 & 1127 & 55 & 1072 & 4,88 \\
\hline 11 & November & 49 & 22 & 1078 & 55 & 1023 & 5,10 \\
\hline 12 & Desember & 49 & 23 & 1127 & 58 & 1069 & 5,14 \\
\hline & Total & 616 & 270 & 13856 & 711 & 13145 & 61,56 \\
\hline & Rata-Rata & 51,4 & 22,5 & 1154,7 & 59,3 & 1095,5 & 5,20 \\
\hline
\end{tabular}

Sumber : PT. Asuransi Sinarmas Cabang Denpasar, 2016

Berdasarkan Tabel 3 dapat dijelaskan bahwa tingkat absensi karyawan PT. Asuransi Sinarmas Cabang Denpasar di Tahun 2016 tergolong tinggi yakni 5,20 persen. Menurut Mudiartha dkk (2001:93), bahwa tingkat absensi yang wajar berada dibawah 3 persen, di atas 3 sampai 10 persen dianggap tinggi, sehingga sangat perlu mendapat perhatian serius dari pihak perusahaan, dikarenakan tingkat absensi yang tinggi adalah salah satu indikator rendahnya kepuasan kerja karyawan. 
Herland Nurtika, Pengaruh Kompensasi Financial dan Kepuasan kerja...

Berdasarkan observasi dan wawancara awal yang dilakukan, dapat dijelaskan bahwa komitmen mereka terhadap organisasi kurang, karena kebanyakan dari mereka menginginkan pekerjaan ditempat lainnya. Masalah kompensasi finansial berupa gaji yang diberikan oleh perusahaan juga masih dirasa tidak adil oleh karyawan walaupun sudah melebihi Upah Minumum Regional (UMR) Kota Denpasar, karena tanggung jawab, resiko dan beban kerja yang diberikan oleh perusahaan lebih besar dibandingkan dengan gaji yang diberkan. Masalah kepuasan kerja juga mempengaruhi tingkat turnover yang tinggi ini, karyawan merasa beban kerja yang sangat berat tidak sebanding dengan apa yang diberikan oleh perusahaan, sehingga mereka merasa kurang puas dalam bekerja.

Tujuan dalam penelitian ini adalah untuk menganalisis pengaruh kompensasi finansial terhadap komitmen organisasi pada PT. Asuransi Sinarmas Cabang Denpasar dan Untuk menganalisis pengaruh kepuasan kerja terhadap komitmen organisasi pada PT. Asuransi Sinarmas Cabang Denpasar.

Bagi ilmu pengetahuan adalah penelitian ini berguna untuk memperkaya secara empirik bidang ilmu manajemen sumber daya manusia, khususnya dalam aspek komitmen organisasi , kompensasi finansial, dan kepuasan kerja, sementara bagi peneliti selanjutnya penelitian ini diharapkan dapat digunakan sebagai bahan pertimbangan bagi pihak manajemen PT. Asuransi Sinarmas Pusat dalam merumuskan kebijakan yang berkaitan dengan kompensasi finansial dan kepuasan kerja pada PT. Asuransi Sinarmas Cabang Denpasar untuk dapat meningkatkan komitmen organisasi karyawan. 
Werther dan Davis (2001) mengatakan bahwa jika diatur dengan benar, kompensasi membantu organisasi mencapai tujuannya serta mendapatkan, memelihara dan menjaga tenaga kerja yang produktif. Kompensasi mempunyai pengaruh yang besar dalam penarikan karyawan, motivasi, produktivitas, dan tingkat perputaran karyawan. Dengan demikian, kompensasi yang diatur dengan benar dapat diprediksi sebagai faktor yang mempengaruhi komitmen organisasi (Benardin dan Russel, 2000).

Penelitian Utami, D. et al. (2013), Hidayat, A.S. (2015), Buraidah et al. (2011), Ricky et al. (2016 dan Arta (2017) menyatakan bahwa kompensasi finansial berpengaruh positif dan signifikan terhadap komitmen organisasi.

$\mathrm{H}_{1}$ : Kompensasi finansial berpengaruh positif dan signifikan terhadap komitmen organisasi

Robbins (2006) dalam Novelia (2011) menyatakan bahwa kepuasan kerja didefinisikan sebagai sikap umum individu terhadap pekerjaannya. Karyawan dapat menilai seberapa puas atau tidak puas dirinya dengan pekerjaannya. Kepuasan kerja dapat ditinjau dari dua sisi, dari sisi karyawan, kepuasan kerja akan memunculkan perasaan menyenangkan dalam bekerja, sedangkan dari sisi perusahaan, kepuasan kerja akan meningkatkan produktivitas, perbaikan sikap dan tingkah laku karyawan dalam memberikan pelayanan prima.

Penelitian Utami, D. et al. (2013), Puspitawati et al. (2014), Parwita, G. (2013), Sijabat (2011) dan Kartika (2012) menyatakan bahwa kepuasan kerja berpengaruh positif dan signifikan terhadap komitmen organisasi.

$\mathrm{H}_{2}$ : Kepuasan kerja berpengaruh positif dan signifikan terhadap komitmen organisasi 


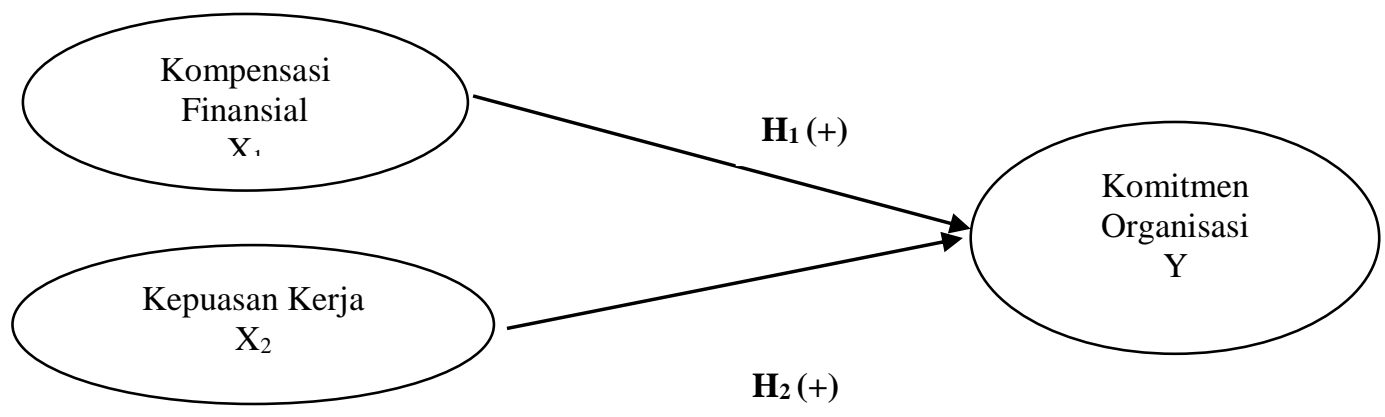

Gambar 1. Kerangka Konsep Penelitian

Sumber: Data Primer Diolah, 2017

\section{METODE PENELITIAN}

Penelitian ini untuk mengetahui pengaruh variabel kompensasi finansial (X1) dan kepuasan kerja (X2), terhadap komitmen organisasi (Y) sebagai variabel terikat. Penelitian ini dilakukan di PT. Asuransi Sinarmas Cabang Denpasar yang berada dijalan Letda Tantular no. 8, Renon. Adapun alasannya dilakukannya penelitian di PT. Asuransi Sinarmas Cabang Denpasar adalah karena terdapat masalah komitmen organisasi, dimana tingginya tingkat turnover karyawan didalam perusahaan diduga karena kompensasi finansial dan kepuasan kerja yang tidak sesuai dan belum adanya penelitian yang dilakukan di PT. Asuransi Sinarmas Cabang Denpasar tentang kompensasi finansial, kepuasan kerja dan komitmen organisasi.

Obyek dalam penelitian ini adalah kompensasi finansial, kepuasan kerja dan komitmen organisasi. Jenis data dalam penelitian ini terbagi menjadi 2 yaitu data kuantitatif dan data kualitatif. Sumber data dalam penelitian ini terbagi menjadi 2 yaitu sumber primer yang diperoleh secara langsung dari responden, diamati dan dicatat untuk pertama kalinya oleh peneliti, data ini didapatkan dengan wawancara 
dan pemberian kuesioner kepada responden sedangkan sumber sekunder adalah data yang sudah ada dari perusahaan.

Populasi dari karyawan PT. Asuransi Sinarmas Cabang Denpasar adalah 49 orang untuk karyawan tetap , maka metode yang akan digunakan adalah teknik sampel jenuh dan semua populasi akan dijadikan sampel dalam penelitian. Karyawan tetap digunakan karena erat kaitannya dengan variabel komitmen organisasi dimana karyawan tetap terikat dengan perusahaan tanpa batasan waktu, sedangkan karyawan kontrak terikat waktu dengan perusahaan sesuai dengan kontrak yang disepakati dengan perusahaan.

Pengujian instrumen dalam penelitian ini adalah Uji validitas, Uji validitas dapat dilakukan dengan mengkorelasikan antara skor faktor dengan skor total dan bila korelasi tiap faktor tersebut positif 0,3 ke atas maka faktor tersebut merupakan construct yang kuat (Sugiyono, 2004:115). Pengujian validitas dalam penelitian ini dilakukan dengan bantuan program SPSS (Statistic Package of Social Science) For Windows. Dan Uji reliabilitas menurut Sugiyono (2009:110) adalah instrument yang bila digunakan beberapa kali untuk mengukur objek yang sama, akan menghasilkan data yang sama. Menurut Umar (2003:126) reliabilitas adalah derajat ketepatan, ketelitian atau keakuratan yang ditunjukkan oleh instrument pengukuran. Pengujian dapat dilakukan secara internal yaitu pengujian dengan menganalisis konsistensi butir-butir yang ada. Teknik uji reliabilitas yang digunakan adalah reliabilitas internal dengan menggunakan rumus Cronbach's

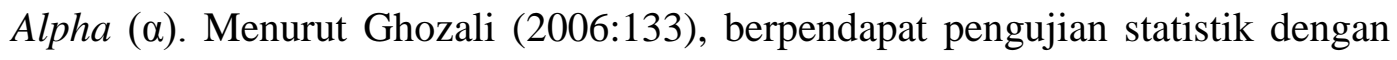


menggunakan teknik statistik cronbach alpha, instrument dikatakan reliabel untuk mengukur variabel bila memiliki nilai alpha lebih besar dari 0,6.

Teknik analisis data yang digunakan dalam penelitian ini adalah model regresi linier berganda. Model regresi linier berganda dalam penelitian ini digunakan untuk mengetahui pengaruh kompensasi finansial dan kepuasan kerja terhadap komitmen organisasi. Model regresi linier berganda yang dimaksud, dirumuskan sebagai berikut

$$
\begin{aligned}
& \mathrm{Y}=\mathrm{a}+\mathrm{b} 1 \mathrm{X} 1+\mathrm{b} 2 \mathrm{X} 2+\mathrm{e} \ldots \ldots \ldots \ldots \ldots \ldots \ldots \ldots \ldots \\
& \text { Dimana }: \\
& \mathrm{Y}=\text { komitmen organisasi } \\
& \mathrm{X} 1=\text { kompensasi finansial } \\
& \mathrm{X} 2=\text { kepuasan kerja } \\
& \mathrm{a}=\text { Constanta } \\
& \mathrm{b} 1=\text { Koefisien variabel X1 } \\
& \mathrm{b} 2=\text { Koefisien variabel X2 } \\
& \mathrm{e} \quad=\text { Error of term }(\text { variabel yang tidak terungkap) }
\end{aligned}
$$

Pengujian hipotesis dalam penelitian ini dapat dilakukan, apabila model regresi linier berganda sudah memenuhi syarat uji asumsi klasik. Uji asumsi klasik dalam penelitian ini adalah Uji normalitas digunakan untuk mengetahui apakah dalam sebuah model regresi, variabel bebas dan variabel terikatnya mempunyai distribusi normal atau tidak. Model yang baik adalah apabila model regresi mempunyai distribusi data normal atau mendekati normal. Hasil analisis uji normalitas data dengan cara melihat normal probability plot yang membandingkan distribusi komulatif dari distribusi normal serta histogram.

Uji multikolinieritas bertujuan untuk mengetahuiapakah model regresi ditemukan adanya korelasiantara variabel bebas (independen). Model yang 
baikseharusnya tidak terjadi korelasi di antara variabel independen. Diteksi terhadap ada tidaknya multikolinieritas yaitu dengan menganalisis matriks korelasi variabel-variabel bebas, dapat juga dilihat pada nilai Tolerence serta nilai Variance Inflation Factor (VIF). Suatu model regresi bebas dari multikolinieritas apabila nilai VIF disekitar angka $<10$ serta Tolerance $>0,10$.

Uji heteroskedastisitas dimaksudkan untuk mengetahui apakah dalam model regresi tidak terjadi ketidaksamaan varian dari residual satu pengamatan ke pengamatan lain. Apabila varian residual satu pengamatan ke pengamatan lain berbeda, maka terjadi heteroskedastisitas. Untuk menentukan ada tidaknya heteroskedastisitas dalam penelitian ini dengan cara melihat grafik Scatterplot antara nilai prediksi variabel dependen dengan residualnya. Dasar analisisnya adalah: 1) Apabila ada pola tertentu seperti titik-titik yang ada membentuk pole tertentu yang teratur maka mengindikasikan telah terjadi heteroskedastisitas. 2) Jika adapola yang jelas serta titik-titik menyebar di atas dandi bawah angka 0 pada sumbu Y, maka tidak terjadi heteroskedastisitas.

Uji kesesuaian model (goodness of fit test) digunakan dalam menguji apakah model persamaan struktural yang diusulkan memiliki kesesuaian (fit) dengan data atau tidak. Pada penelitian ini pengujian goodness of fitakan diuji melalui uji $\mathrm{F}$ yang jika $F_{\text {hitung }}>F_{\text {tabel }}$ dan nilai probabilitas 0.05 lebih besar dari nilai probabilitas Sig atau $(0.05>\mathrm{Sig})$.

Uji t digunakan untuk mengetahui signifikan analisis regresi berganda dengan membandingkan antara nilai probabilitas 0.05 dengan nilai probabilitas Sig atau $(0.05 \leq$ Sig), maka Ho diterima dan Ha ditolak yang menyatakan tidak 
adanya signifikan. Sedangkan jika nilai probabilitas 0.05 lebih besar dari nilai probabilitas Sig atau (0.05>Sig), maka Ho ditolak dan $\mathrm{H}_{1}$ diterima. Formulasi uji $\mathrm{t}$ adalah $\mathrm{Y}=\mathrm{b} 0+\mathrm{b} 1 \mathrm{X} 1+\mathrm{b} 2 \mathrm{X} 2+\mathrm{e}$

\section{HASIL DAN PEMBAHASAN}

Uji validitas digunakan untuk mengukur suatu kuesioner. Dalam hal ini digunakan butir pertanyaan yang diharapkan dapat secara tepat mengungkapkan variabel yang diukur. Tabel 4 menunjukkan bahwa seluruh butir pernyataan yang digunakan dalam penelitian ini adalah valid, hal ini bisa dilihat dari nilai masingmasing item pertanyaan memiliki nilai Corrected Item-Total Correlation yang lebih besar dari 0,30. Teknik yang digunakan untuk menguji reliabilitas kuesioner dalam penelitian ini adalah menggunakan rumus koefisien Cronbach's Alpha, dengan cara membandingkan nilai Alpha dengan standarnya. Hasil uji validitas dapat dilihat pada Tabel 4.

Tabel 4. Hasil Uji Validitas

\begin{tabular}{lccc}
\hline Variabel & Item & $\begin{array}{c}\text { Corrected } \\
\text { Item-Total } \\
\text { Correlation }\end{array}$ & Ket. \\
\hline Komitmen Organisasi (Y) & Y1.1 & 0.759 & Valid \\
& Y1.2 & 0.831 & Valid \\
& Y1.3 & 0.731 & Valid \\
\hline Kompensasi Finansial & X1.1 & 0,737 & Valid \\
(X1) & X1.2 & 0.696 & Valid \\
& X1.3 & 0.813 & Valid \\
& X1.4 & 0.617 & Valid \\
\hline Kepuasan Kerja (X2) & X2.1 & 0.627 & Valid \\
& X2.2 & 0.534 & Valid \\
& X2.3 & 0.598 & Valid \\
& X2.4 & 0.778 & Valid \\
& X2.5 & 0,674 & Valid \\
\hline
\end{tabular}

Sumber : Hasil Pengolahan Data, 2017 
Reliabilitas suatu konstruk variabel dikatakan baik jika memiliki nilai Cronbach's Alpha yang lebih besar dari 0,60. Hasil uji reliabilitas pada penelitian ini dapat dilihat pada Tabel 5 .

Tabel 5. Hasil Uji Reliabilitas

\begin{tabular}{lcl}
\hline Variabel & Cronbach's Alpha & Ket \\
\hline Komitmen Organisasi (Y) & 0.663 & Reliabel \\
Kompensasi Finansial (X1) & 0.688 & Reliabel \\
Kepuasan Kerja (X2) & 0.648 & Reliabel \\
\hline
\end{tabular}

Sumber : Hasil Pengolahan Data, 2017

Tabel 5 menunjukkan bahwa variabel-variabel yang digunakan dalam penelitian ini adalah reliabel karena keseluruhan variabel memiliki nilai Cronbach's Alpha yang lebih besar dari 0,60 sehingga layak digunakan untuk mengukur kuesioner dalam penelitian ini.

Tabel 6. Hasil Penilaian Responden Terhadap Variabel Kompensasi Finansial

\begin{tabular}{llllllllll}
\hline \multirow{2}{*}{ No } & \multirow{2}{*}{ Indikator } & \multicolumn{9}{c}{ Proporsi Jawaban Responden } & $\begin{array}{c}\text { Rata- } \\
\text { Rata }\end{array}$ & Kriteria \\
\cline { 3 - 7 } 1 & Upah dan gaji & 1 & 3 & 6 & 10 & 29 & 4.28 & $\begin{array}{c}\text { Sangat } \\
\text { Baik }\end{array}$ \\
2 & Insentif & 1 & 3 & 4 & 12 & 29 & 4.28 & $\begin{array}{c}\text { Sangat } \\
\text { Baik }\end{array}$ \\
3 & Tunjangan & 2 & 3 & 8 & 9 & 27 & 4.14 & Baik \\
4 & Fasilitas & 1 & 1 & 3 & 6 & 38 & 4.61 & $\begin{array}{c}\text { Sangat } \\
\text { Baik }\end{array}$ \\
\hline
\end{tabular}

Sumber : Data diolah 
Tabel 6 menunjukkan bahwa bahwa skor untuk variabel kompensasi adalah 4.2 ini menyatakan bahwa karyawan setuju terhadap variabel kompensasi finansial pada PT. Asuransi Sinarmas Cabang Denpasar.

\section{Tabel 7. Hasil Penilaian Responden Terhadap Variabel Kepuasan Kerja}

\begin{tabular}{|c|c|c|c|c|c|c|c|c|}
\hline \multirow{2}{*}{ No } & \multirow{2}{*}{ Indikator } & \multicolumn{5}{|c|}{ Proporsi Jawaban Responden } & \multirow{2}{*}{$\begin{array}{l}\text { Rata- } \\
\text { Rata }\end{array}$} & \multirow[t]{2}{*}{ Kriteria } \\
\hline & & STS & TS & $\mathrm{N}$ & $\mathrm{S}$ & SS & & \\
\hline 1 & Pengawasan & 3 & 4 & 8 & 9 & 25 & 3.96 & Baik \\
\hline 2 & Rekan kerja & 1 & 6 & 11 & 9 & 22 & 3.92 & Baik \\
\hline 3 & Gaji & 1 & 3 & 9 & 17 & 19 & 4.02 & Baik \\
\hline 4 & Promosi & 3 & 6 & 4 & 10 & 26 & 3.98 & Baik \\
\hline 5 & Pekerjaan & 3 & 5 & 7 & 13 & 21 & 3.90 & Baik \\
\hline & & Kerja & & & & & 4.00 & Baik \\
\hline
\end{tabular}

Sumber : Data diolah

Tabel 7 menunjukkan bahwa bahwa skor untuk variabel kepuasan kerja adalah 4.00, ini menyatakan bahwa karyawan setuju terhadap variabel kepuasan kerja pada PT. Asuransi Sinarmas Cabang Denpasar.

Tabel 8 Hasil Penilaian Responden Terhadap Variabel Komitmen Organisasi

\begin{tabular}{|c|c|c|c|c|c|c|c|c|}
\hline \multirow{2}{*}{ No } & \multirow{2}{*}{ Indikator } & \multicolumn{5}{|c|}{ Proporsi Jawaban Responden } & \multirow{2}{*}{$\begin{array}{l}\text { Rata- } \\
\text { Rata }\end{array}$} & \multirow{2}{*}{ Kriteria } \\
\hline & & STS & TS & $\mathrm{N}$ & $S$ & SS & & \\
\hline 1 & Komitmen afektif & 1 & 1 & 3 & 6 & 38 & 4.60 & $\begin{array}{c}\text { Sangat } \\
\text { Baik }\end{array}$ \\
\hline 2 & Komitmen berkelanjutan & 1 & 5 & 3 & 10 & 30 & 4.30 & $\begin{array}{c}\text { Sangat } \\
\text { Baik }\end{array}$ \\
\hline 3 & Komitmen normatif & 1 & 1 & 7 & 7 & 33 & 4.40 & $\begin{array}{c}\text { Sangat } \\
\text { Baik }\end{array}$ \\
\hline \multicolumn{7}{|c|}{ Komitmen Organisasi } & 4.44 & $\begin{array}{c}\text { Sangat } \\
\text { Baik }\end{array}$ \\
\hline
\end{tabular}

Sumber : Data diolah, 2017 
Tabel 8 menunjukkan bahwa bahwa skor untuk variabel komitmen organisasi adalah 4.44 , ini menyatakan bahwa karyawan setuju terhadap variabel organisasi pada PT. Asuransi Sinarmas Cabang Denpasar.

Teknik analisis regresi linier berganda digunakan untuk menguji pengaruh dua atau lebih variabel bebas terhadap satu variabel terikat. Hasil uji analisis regresi linear berganda terhadap tiga variabel, yaitu kompensasi finansial, kepuasan kerja dan komitmen organisasi dapat dilihat pada Tabel 9 berikut ini.

Tabel 9. Hasil Analisis Regresi Linier Berganda

\begin{tabular}{|c|c|c|c|c|c|}
\hline \multicolumn{6}{|c|}{ Coefficients $^{\mathrm{a}}$} \\
\hline \multirow[t]{2}{*}{ Model } & \multicolumn{2}{|c|}{ Unstandardized Coefficients } & Standardized Coefficients & \multirow[t]{2}{*}{$\mathrm{t}$} & \multirow[t]{2}{*}{ Sig. } \\
\hline & $\mathrm{B}$ & Std. Error & Beta & & \\
\hline 1 (Constant) & 3.602 & 1.619 & & 2.225 & .031 \\
\hline Kompensasi & .194 & .090 & .25 & 2.162 & .036 \\
\hline Kepuasan Kerja & .322 & .068 & .55 & 4.723 & .000 \\
\hline R Square & & & & & 0,475 \\
\hline Sig. Fhitung & & & & & 0,000 \\
\hline Fhitung & & & & & 20,845 \\
\hline
\end{tabular}

Sumber : Hasil Pengolahan Data, 2017

Berdasarkan Tabel 9 model regresi yang digunakan adalah sebagai berikut:

$$
Y=3.602+0.194 X 1+0.322 X 2 \text {. }
$$

Konstanta sebesar 3.602 menunjukkan bahwa jika variabel-variabel independen (kompensasi finansial dan kepuasan kerja) diasumsikan tidak mengalami perubahan (konstan) maka nilai $\mathrm{Y}$ (komitmen organisasi) adalah sebesar 3.602 satuan. Nilai koefisien regresi kompensasi finansial $(X 1)=0,194$, menunjukkan bahwa terdapat pengaruh positif antara variabel kompensasi finansial (X1) terhadap variabel komitmen organisasi (Y) sebesar 0,087. Artinya 
apabila kompensasi finansial (X1) naik sebesar satu satuan sementara kepuasan kerja (X2) diasumsikan tetap, maka komitmen organisasi akan meningkat sebesar 0,194 satuan. Nilai koefisien regresi kepuasan kerja $(X 2)=0,322$, menunjukkan bahwa terdapat pengaruh positif antara variabel kepuasan kerja (X2) terhadap komitmen organisasi (Y) sebesar 0,279. Artinya apabila kepuasan kerja (X2) naik sebesar satu satuan sementara kompensasi finansial (X1) diasumsikan tetap, maka komitmen organisasi akan meningkat sebesar 0,279 satuan.

Hasil uji koefisien determinasi menunjukkan Adjusted $\mathrm{R}^{2}$ sebesar 0,453. Berarti kontribusi variabel independen terhadap variabel dependen sebesar 45,3 persen dan sisanya sebesar 54,7 persen ditentukan oleh faktor lain diluar model yang tidak terdeteksi dalam penelitian ini. Hasil uji $\mathrm{F}$ menunjukkan nilai $\mathrm{F}$ hitung sebesar 20.845 dengan signifikan sebesar 0,000. Nilai signifikan tersebut lebih kecil daripada 0,05, sehingga disimpulkan bahwa kompensasi finansial dan kepuasan kerja berpengaruh terhadap komitmen organisasi dan variabel independen layak digunakan untuk memprediksi variabel dependen, sehingga pembuktian hipotesis dapat dilakukan.

Hasil uji t menunjukkan signifikansi $t_{\text {hitung }}(0,036) \leq 0,05$ maka Ho ditolak. Hal ini membuktikan bahwa kompensasi finansial berpengaruh positif pada komitmen organisasi. Ini berarti bahwa apabila kompensasi finansial semakin meningkat, maka akan semakin meningkatkan komitmen organisasi di PT Asuransi Sinarmas Cabang Denpasar. Variabel kepuasan kerja memiliki signifikansi thitung $(0,000) \leq 0,05$ maka Ho ditolak. Hal ini membuktikan bahwa kepuasan kerja berpengaruh positif dan signifikan terhadap komitmen organisasi 
di PT Asuransi Sinarmas Cabang Denpasar. Ini berarti bahwa apabila kepuasan kerja semakin meningkat, maka akan cenderung meningkatkan komitmen organisasi di PT Asuransi Sinarmas Cabang Denpasar.

Uji normalitas bertujuan untuk menguji apakah variabel-variabel yang digunakan dalam penelitian ini telah berdistribusi normal. Model regresi yang baik adalah model yang memiliki distribusi normal. Pengujian normalitas dapat dilakukan dengan menggunakan One Sample Kolmogorov-Smirnov Test, dengan taraf signifikan 0,05 atau 5\%. Jika signifikan yang dihasilkan> 0,05 maka distribusi datanya dikatakan normal. Sebaliknya jika signifikan yang dihasilkan $<0,05$ maka data tidak terdistribusi secara normal. Hasil perhitungan nilai Kolmogorov-Smirnov Test untuk model yang diperoleh dapat dilihat pada Tabel 7.

Tabel 10. Hasil Uji Normalitas (Kolmogorov-Smirnov Test) One-Sample Kolmogorov-Smirnov Test

Unstandardized Residual

$N$

Normal Parameters ${ }^{a, b}$

\begin{tabular}{llr} 
& Std. Deviation & 1.64223141 \\
& Absolute & .081 \\
Most Extreme Differences & Positive & .060 \\
& Negative & -.081 \\
Kolmogorov-Smirnov Z & & .565 \\
Asymp. Sig. (2-tailed) & & .907 \\
\hline Sumber : Hasil Pengolahan Data, 2017
\end{tabular}

.0000000

.081

.060

.081

\section{9}

Hasil uji normalitas Kolmogorov-Smirnov Test menunjukkan bahwa berdasarkan nilai Sig (2-tailed), dapat dilihat bahwa besarnya Sig (2-tailed) $(0,472)>$ dari taraf signifikan $(0,05)$, sehingga dapat disimpulkan bahwa variabel 
kompensasi finansial dan kepuasan kerja terhadap komitmen organisasi berdistribusi secara normal.

Uji multikolinearitas bertujuan untuk menguji apakah pada model regresi ditemukan adanya kolerasi antar variabel bebas. Untuk menguji adanya multikolinearitas dapat dilihat melalui nilai Variance Inflantion Factor (VIF) dan tolerancevalue untuk masing-masing variabel bebas. Apabila tolerance value di atas 0,10 dan VIF kurang dari 10 maka dikatakan tidak terdapat gejala multikolinearitas. Hasil perhitungan nilai VIF untuk pengujian multikolinearitas antara sesama variabel bebas dapat dilihat pada Tabel 8 berikut.

\section{Tabel 11. Hasil Uji Multikolinearitas}

\begin{tabular}{|c|c|c|}
\hline \multicolumn{3}{|c|}{ Coefficients $^{\mathrm{a}}$} \\
\hline Model & Collinearity & Statistics \\
\hline & Tolerance & $V I F$ \\
\hline (Constant) & & \\
\hline 1 Kompensasi & .842 & 1.188 \\
\hline Kepuasan Kerja & .842 & 1.188 \\
\hline
\end{tabular}

Hasil nilai VIF pada Tabel 11, menunjukkan variabel bebas dalam model regresi tidak saling berkolerasi. Diperoleh nilai VIF untuk masing-masing variabel bebas kurang dari 10 dan tolerance value berada diatas 0,10 . Hal ini menunjukkan tidak adanya korelasi antara sesama variabel bebas dalam model regresi dan disimpulkan tidak terdapat masalah multikolinearitas diantara sesama variabel bebas dalam model regresi.

Uji heteroskedastisitas bertujuan untuk menguji apakah dalam sebuah model regresi terjadi ketidaksamaan varians dari residual atas satu pengamatan ke pengamatan yang lain. Jika varians dari residual suatu pengamatan ke pengamatan 
lain tetap, maka disebut homokedastisitas dan jika berbeda disebut heterokedastisitas. Untuk mendeteksi adanya heterokedastisitas pada penelitian ini menggunakan uji Gletser. Jika signifikan di atas 5 persen maka disimpulkan model regresi tidak mengandung adanya heteroskedastisitas. Adapun hasil pengujian dapat dilihat pada Tabel 12 berikut.

Tabel 12. Hasil Uji Heteroskedastisitas

\begin{tabular}{|c|c|c|c|c|c|c|}
\hline \multicolumn{7}{|c|}{ Coefficients $^{\mathrm{a}}$} \\
\hline \multirow[t]{2}{*}{ Model } & & Unstandardizec & Coefficients & Standardized & $\mathrm{t}$ & Sig. \\
\hline & & B & Std. Error & Beta & & \\
\hline \multirow{3}{*}{1} & (Constant) & 5.373 & .850 & & 6.323 & .000 \\
\hline & Kompensasi & -.122 & .047 & -.336 & -2.590 & .283 \\
\hline & Kepuasan Kerja & -.103 & .036 & -.371 & -2.866 & .242 \\
\hline
\end{tabular}

Sumber : Hasil Pengolahan Data, 2017

Tabel 12 menunjukkan hasil perhitungan nilai signifikansi masing-masing variabel yang menunjukkan level sig $>\alpha(0,05)$ yaitu 0,283 untuk kompensasi dan 0,242 untuk kepuasan kerja. Hal ini berarti model regresi yang digunakan dalam penelitian ini terbebas dari heterokedastisitas.

Berdasarkan hasil yang disajikan pada uji t menunjukkan bahwa, angka lebih kecil dari pada taraf nyata dalam penelitian ini yaitu 0,05 . Hal ini menunjukkan variabel kompensasi finansial berpengaruh positif terhadap komitmen organisasi. Berarti hipotesis pertama $\left(\mathrm{H}_{1}\right)$ dapat diterima yaitu Kompensasi Finansial memiliki pengaruh positif dan signifikan terhadap komitmen organisasi. Kompensasi Finansial mempunyai pengaruh yang besar dalam penarikan karyawan, motivasi, produktivitas, dan tingkat perputaran karyawan. Dengan demikian, apabila kompensasi finansial semakin meningkat, maka akan semakin meningkatkan komitmen organisasi di PT Asuransi Sinarmas 
Cabang Denpasar. Hasil pembahasan didukung oleh penelitian Utami, D. et al. (2013), Hidayat, A.S. (2015), Buraidah et al. (2011), Ricky et al. (2016 dan Arta (2017). yang menunjukkan bahwa kompensasi finansial berpengaruh positif dan signifikan terhadap komitmen organisasi. Kompensasi finansial merupakan imbal jasa yang diberikan oleh perusahaan (organisasi) kepada karyawannya. Sehingga apabila kompensasi finansial yang diberikan perusahaan baik, maka komitmen organisasi di perusahaan semakin meningkat.

Berdasarkan hasil yang disajikan pada uji t menunjukkan bahwa, angka lebih kecil daripada taraf nyata dalam penelitian ini yaitu 0,05 . Hal ini menunjukkan variabel kepuasan kerja berpengaruh positif terhadap komitmen organisasi. Berarti hipotesis pertama $\left(\mathrm{H}_{2}\right)$ dapat diterima yaitu Kepuasan kerja memiliki pengaruh positif dan signifikan terhadap komitmen organisasi. Kepuasan kerja dapat ditinjau dari dua sisi, dari sisi karyawan, kepuasan kerja akan memunculkan perasaan menyenangkan dalam bekerja, sedangkan dari sisi perusahaan, kepuasan kerja akan meningkatkan produktivitas, perbaikan sikap dan tingkah laku karyawan dalam memberikan pelayanan. Dengan demikian, apabila kepuasan kerja semakin meningkat, maka akan semakin meningkatkan komitmen organisasi di PT Asuransi Sinarmas Cabang Denpasar. Hasil pembahasan didukung oleh penelitian Penelitian Utami, D. et al. (2013), Puspitawati et al. (2014), Parwita, G. (2013), Sijabat (2011) dan Kartika (2012). yang menunjukkan bahwa kepuasan kerja berpengaruh positif dan signifikan terhadap komitmen organisasi. karyawan yang relatif puas dengan pekerjaannya akan lebih berkomitmen pada organisasi dan karyawan yang berkomitmen terhadap 
organisasi lebih mungkin mendapat kepuasan yang lebih besar. Sehingga apabila kepuasan kerja yang diberikan perusahaan baik, maka komitmen organisasi di perusahaan semakin meningkat.

\section{SIMPULAN DAN SARAN}

Simpulan dari penelitian berikut adalah Kompensasi Finansial berpengaruh positif terhadap komitmen organisasi pada PT. Asuransi Sinarmas Cabang Denpasar. Hal ini menunjukkan bahwa semakin baik kompensasi finansial yang diberikan oleh pimpinan perusahaan, maka komitmen organisasi juga akan meningkat. Kepuasan Kerja berpengaruh positif terhadap komitmen organisasi pada PT. Asuransi Sinarmas Cabang Denpasar. Hal ini menunjukkan bahwa semakin baik kepuasan kerja yang dirasakan karyawan, maka komitmen organisasi juga akan meningkat.

Adapun saran yang dapat diberikan adalah sebagai berikut Manajer perusahaan perlu untuk memperhatikan jumlah kompensasi finansial yang diberikan khususnya tunjangan, karena pada indikator ini memiliki nilai yang paling rendah. Hal ini perlu dilakukan agar karyawan bisa lebih meningkatkan kinerjanya dan lebih berkomitmen kepada perusahaan. Manajer perusahaan perlu untuk memperhatikan beban pekerjaan yang diberikan kepada karyawannya, agar karyawan selalu merasa puas dan bisa menyelesaikan setiap pekerjaan dengan baik, karena pada indikator ini memiliki nilai yang paling rendah.

Manajer perusahaan perlu untuk terus berusaha mempertahankan karyawan agar mereka merasa rugi jika meninggalkan perusahaan. Nilai pada indikator ini paling kecil. Manajer perlu memperhatikan tingkat kompensasi finansial yang 
diberikan dan beban pekerjaan yang mereka lakukan agar komitmen karyawan meningkat. Bagi akademisi adalah perlu dilakukan penelitian diperusahaan ini dengan variabel selain kompensasi finansial, kepuasan kerja dan komitmen organisasi.

\section{REFERENSI}

Anastasia, T. dan Sutanto, E. M. 2013. Pengaruh Motivasi Kerja Dan Kepuasan Kerja Terhadap Komitmen Organisasional Karyawan PT. DAI KNIFE Surabaya. Skripsi. Fakultas Ekonomi Universitas Kristen Petra.

Ardana, K., Mujiati, W. dan Sriathi, A.A.A. 2011. Perilaku Keorganisasian. Cetakan 1. Yogyakarta: Graha Ilmu.

Arta, I. G. 2017. Pengaruh kompensasi terhadap komitmen organisasional dan turnover intention pada Agent Pru Megas. E-Jurnal Manajemen Unud, 6(8): 4156-4184.

Atmojo M. 2012. The Influence of Transformational Leadership on Job Satisfaction, Organizational Commitment, and Employee Performance. International Research Journal of Business Studies, 5(2): 113-128.

Armstrong, M. 1990. A Handbook Of Human Resource Management (Alih Bahasa: Sofyan Cikmat, Haryanto). Jakarta: PT. Elex Media Komputindo.

Bakhshi, A. 2009. Organizational justice perceptions as predictor of job satisfaction and organization commitment. International Journal of Business and Management, 4(9): 145-154

Buraidah, L. 2011. Pengaruh Kompensasi Dan Motivasi Kerja Terhadap Komitmen Organisasi Di Organisasi Pendidikan Islam. Tesis. Pasca Sarjana Psikologi Universitas Gunadarma.

Chukwuma, E. M. 2014. Effect of Motivation on Employee Productivity: A Study of Manufacturing Companies in Nnewi. International Journal of Managerial Studies and Research, 2(7): 137-145.

Dewi, A.A.U. 2014. Pengaruh Kompensasi dan Kepuasan kerja terhadap Komitmen Organisasi pada PT. Bali Marine Walk. E-Jurnal Manajemen Universitas Udayana, 3(11): 3257-3273. 
Gibson, J. L. 2002. Organisasi Perilaku-Struktur-proses. Terjemahan, Edisi V, Jakarta: Penerbit Erlangga.

Gillies, D.A. 1994. Nursing Management a System Approach. Third edition. Philadelphia. WB Saunders.

Hasibuan, M. S. P. 2006. Manajemen Sumber Daya Manusia, Jakarta: PT Haji Masagung.

Hee, J. 2015. The impact of supervisory support on organizational commitment, career satisfaction, and turnover intention for hospitality frontline employees. Journal of Human Resources in Hospitality, 14(1): 68-89

Hidayat, A. S. 2015. Pengaruh kompensasi dan pengembangan karir terhadap komitmen organisasi (studi kasus pada PT. Bank BRI Syariah Cabang Bandung Suniaraja). Jurnal Ecodemica, 3(1): 334-341.

Ibnu Umar, S. 1994. Variabel-variabel Individual Peramal Keberhasilan Transmigran. Disertasi, Universitas Indonesia.

John, B. H., Russel, J. C.A. 1993. Human Resources Management: An Experimental Approach. Singapura: Mc. Graw Hill inc.

Kartika, R. G. 2012. Pengaruh Kepuasan Kerja Terhadap Komitmen Organisasional Pada Karyawan PT. Hellomotion Korpora Indonesia. Skirpsi. Fakultas Ekonomi Universitas Indonesia.

Khan, A.S. 2015. The study of organization commitment and job satisfaction among hospital nurses. a survey of district hospitals of dera ismail khan. Global Journal of Management and Business Research: A Administration and Management, 15(1): 149-162.

Leo, C. 2012. Analisis pengaruh kepuasan kerja terhadap komitmen organisasi pada karyawan RSU PKU Muhammadiyah Bantul. Respository UMY, 5(2): 124-139.

Mathis, R.L. and Jackson, J.H. 2001. Manajemen Sumber Daya Manusia. Buku 1 dan Buku 2, Terjemahan. Jakarta: Salemba Empat.

Meyer, J. P. and Allen, N. J. 1997. Commitment in the Workplace: Theory, research, and application, California : SAGE Publication, Inc.

Meyer, J. P. 2004. Employee commitment and motivation: a conceptual analysis and integrative model. Journal of Applied Psychology, 89(6): 991-1007. 
Milkovich, G. T. and Newman, J. M. 2002. Compensation, 7th edition. New York: Mc Graw Hill.

Muayanah, S. 2017. Pengaruh kompensasi, lingkungan kerja dan komitmen organisasi terhadap organizational citizenship behavior dengan kepuasan kerja sebagai variabel intervening (studi kasus pada karyawan PT. fajar lestari sejati Semarang). Journal of Management, 3(3): 126-137.

Mudiartha, W. 2001. Manajemen Sumber Daya Manusia. UPT Penerbit Universitas Udayana.

Mudiartha, W., Mujiati, N.W. dan Ardana, K. 2011. Manajemen Sumber Daya Manusia, Yogyakarta: Graha Ilmu.

Murgianto. 2016. The effects of commitment, competence, work satisfaction on motivation and performance of employees at integrated service office East Java. International Journal of Advanced Research, 3(1): 378-396.

Nawab, S. and Komal K. B. 2011. Influence of employee compensation on organizational commitment and job satisfaction: a case study of educational sector of Pakistan. International Journal of Business and Social Science, 2(8): 25-32.

Omollo, P. A. 2015. Effect of motivation on employee performance of commercial banks in Kenya: a case study of Kenya commercial bank in Migori Country. International Journal of Human Resource Studies, 5(2): 87-103.

Prasodjo, R. K., Setiawan, R. 2016. Pengaruh kompensasi finansial dan non finansial terhadap komitmen organisasional karyawan pada Pelangi Minimarket. Agora, 4(2): 71-75.

Puspitawati, N.M.D., Riana, I. G. 2014. Pengaruh kepuasan kerja terhadap komitmen organisasional dan kualitas layanan. Jurnal Manajemen Strategi Bisnis dan Kewirausahaan, 8(1): 68-80.

Robbins, S. P. 1996. Perilaku Organisasi: Konsep, Kontroversi, Aplikasi (alih bahasa: Hadyana Pujaatmaka). Jakarta: PT. Ikrar Mandiriabadi.

Robbins, S. P. 2001. Perilaku Organisasi. Edisi Ke Delapan, Jilid 1 \& 2. Jakarta: PT. Prihalindo.

Simamora, H. 2006. Manajemen Sumber Daya Manusia, edisi ketiga, Cetakan kedua, Yogyakarta: Penerbitan STIE YKPN. 
Sijabat, J. 2011. Pengaruh kepuasan kerja terhadap komitmen organisasi dan keinginan untuk pindah. Jurnal Manajemen UNH, 19(3): 592-608.

Škudienè, V. 2005. Impact of leadership styles on employees organizational commitment in Lithuanian manufacturing companies. Journal of Service Science, 6(1): 139-152.

Sopiah. 2008. Perilaku Organisasi. Yogyakarta: Andi.

Spector, P.E. 2000. Industrial and Organizational Psychology: Research and Practise. New York: John Wiley and Sons

Sumarto. 2009. Meningkatkan komitmen dan kepuasan untuk menyurutkan niat keluar. Jurnal Manajemen dan Kewirausahaan, 11(2): 116-125.

Surya, G. B. P. 2013. Pengaruh Kepuasan Kerja Terhadap Komitmen Organisasi Dan Disiplin Kerja. Tesis. Pasca Sarjana Universitas Udayana.

Syauta, J.H. 2012. The influence of organizational culture, organizational commitment to job satisfaction and employee performance (study at municipal waterworks of Jayapura, Papua Indonesia). International Journal of Business and Management Invention, 1(1): 69-76.

Sutrisno, E. (2012). Sumber Daya Manusia. Surabaya: Gramedia.

Suwatno dan Priansa, D. J. 2011. Manajemen SDM Dalam Organisasi Publik dan Bisnis. Bandung: Alfabeta.

Trihendradi, C. 2012. Step by Step SPSS 20 Analisis Data Statistik. Yogyakarta: Andi.

Tulus, M. A. 1996. Manajemen Sumber Daya Manusia. Jakarta: PT. Gramedia Pustaka Utama.

Vladica, M. 2014. Organizational commitment and job satisfaction among nurses in Serbia: a factor analysis. Nursing outlook, 6(2): 415-427.

Warsi, S. 2009. Study on relationship between organizational commitment and its determinants among private sector employees of Pakistan. International Review of Business Research Papers, 5(3): 399-410.

Weihui, F. 2013. The impact of caring climate, job satisfaction, and organizational commitment on job performance of employees in a China's insurance company. Journal of Business Ethics, 124(2): 339-349. 
Herland Nurtika, Pengaruh Kompensasi Financial dan Kepuasan kerja...

Werther, W. B. dan Davis, J. K. 1996. Human Resources And Personnel Management. (5th edition). New York: McGraw-Hill, Inc. (International edition).

Wibawa, B. M. 2016. Pengaruh kompensasi finansial dan non finansial terhadap kinerja karyawan yang dimediasi oleh motivasi (studi pada karyawan tetap CV. bells stars Malang). Jurnal Administrasi Bisnis, 31(1): 81-94.

Zopiatis, A.C. P. and Theocharous, A.L. 2014. Job involvement, commitmet, satis faction and turnover: Evidence from hotel employees in Cyprus. Tourism Management, 41(1): 129-140. 